\section{Poetic self-portrait}

Moulds of Understanding: a Pattern of Natural Philosophy. By Joseph Needham. Pp. 320. (Allen and Unwin: London, April 1976.) £7.75.

JOSEPH NeEdhaM is so widely known personally that it must be almost impossible to find a detached reviewer for any of his works. I certainly cannot claim to be detached. This collection of essays confirms one's respect even though it may not convert one to his political convictions. It waves a wide arm over the extensive view he has of ethical imperatives, human love and the sense of what is holy. For this is what these essays are about, even though their titles and their content are scientific in origin and substance.

To call the essays $A$ Pattern of Natural Philosophy is to stretch the phrase far beyond its traditional use. They have been selected by Gary Werskey, obviously with a bias towards one aspect of Needham's thought-the political-so that they coalesce into a self-portrait, an animated image of a man who has never forgotten his personal beginnings, but never lowers his sights from the destiny of human kind. Cambridge has been his immediate world, described in an essay of 1932 in poetic language which acknowledges his debt to those contemporaries who chose poetry itself as their way of life.

To those who know only his Chinese work or the earlier embryology, it will come as a surprise to find orthodox Christian religion playing a large part in the formation of his outlook both then and now. One might expect, of course, to find early evidence of his well-known socialist convictions, which he has exhibited ever since with both style and humility which others might do well to emulate, whatever their political convictions may be. But it is fascinating to find judgements of great weight being derived from an appreciation of the numinous elements in the traditional church liturgy (the exponents of so-called popularised versions of the long familiar liturgy in both Anglican and Roman churches might learn something to their advantage from what Needham has to say on this subject).

The other essays are grouped under the headings 'Understanding' (all three concerned in some way or other with science and religion), 'Process' (three studies of evolution considered in relation to the organisational interpretation of the Second Law of
Thermodynamics), 'Process and Understanding' (three presentations of a view of man, and particularly scientific man, in a future society formed as much by religious enlightenment as by universal socialism). The final essay is a brief attempt to relate the current Chinese experience to what Needham believes are the World's needs.

One could wish to have more of his rebuttal of the fashionable anti-science of today. For, although a socialism we cannot all accept and a religion for which each of us must be free to seek an alternative, give shape to Needham's philosophy, the solid substance of it is universal science, a progressive science whose development in East and West has played a part in the evolution of the human species just as much as any more obviously biological factor.

Apart from anything else it is a most entertaining book to read, because it is full of good humour and courtesy. He treats his reader by the light of one of his favourite Confucian precepts: "Behave to every man as one receiving a great guest".

Frank Greenaway

Frank Greenaway is Keeper of the Department of Chemistry at the Science Museum, London, UK.

\section{Delight in animal form}

Starfish, Jellyfish, and the Order of Life: Issues in Nineteenth-Century Sciences. (Yale Studies in the History of Science and Medicine, Vol. 10.) By Mary P. Winsor, Pp. $\mathrm{x}+228$. (Yale University: New Haven and London, January 1976.) $£ 10.50$.

MARY PICKARD Winsor's Starfish, Jellyfish and the Order of Life is the tenth in a series of works developed from $\mathrm{PhD}$ theses. Her original study was of "Issues in the Classification of Radiates" - a history of the decline and fragmentation of a miscellany of lower Invertebrates so collected together by Cuvier as one of the four major divisions of the Animal Kingdom. Professor Winsor sees the need "to follow scientists into the farthest corners of their research, lest the historian should mirror uncritically their own self-portrait" and to "go beyond ... textbooks, prefaces and essays intended for the general public". This book is successfully illustrated by half-tone offset lithos of the (mostly) lithographic plates. There is a lively interest in, and competent assessment of MacLeay's Quinorianism, the early study of Alternation of Generations by the student priest Michael Sars of Norway and the Dane Johan Japetus Smith Steenstrup. The young, somewhat erratic, but already the probing doubter T. H. Huxley's relationship with W. S. MacLeay is splendidly documented, and there are a whole sequence of discoveries made in the Agassiz Library at Harvard which houses Louis' and his son Alexander's collection of annotated offprints. That radial starfish had bilateral larvae, as Johannes Müller observed on Heligoland, was a great trial to Louis. Moreover many illustrations of what varieties of meaning lay behind the description "Natural Classification" are presented with sufficient documentation. A rich and full book for historians of science, of marine biology and those zoologists who may still delight in animal form. Darwin was much more closely involved in this story than Dr Winsor realises. Her attempts in her glossary to explain the Animals to the historians range at times from the naive to the grotesque. The bibliographies are remarkably good. The writing has wit and elegance.

Sydney Smith

Sydney Smith is a lecturer in the Department of Zoology at the University of Cambridge, UK.

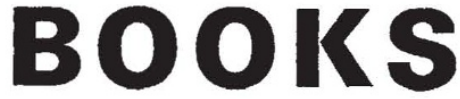

ON PURE AND APPLIED SCIENCE

Books reviewed or mentioned in this journal are available from stock.

Catalogues on application. Please state interests.

\section{SCIENTIFIC LIBRARY}

ANNUAL SUBSCRIPTION from $£ 5.00$

Reduced rates for multiple subscriptions Available in U.K. only

Prospectus free on request

\section{H. K. LFWIS \& Co. Itd. \\ LONDON: 136 GUWER STREET,} WC1E 6BS

Telephone : 01-387 4282 